\title{
BIMBINGAN TEKNIS PEMBUATAN APLIKASI GOOLE FORM UNTUK MENINGKATKAN KOMPETENSI GURU MIN 1 KETAPANG
}

\author{
Supriadi \\ Kepala MIN 1 Ketapang \\ Email: supriadiketapang@ymail.com
}

\begin{abstract}
The Implementation of Practical Assistance as an Effort to Enhance Teacher Competence in Optimizing Goole Form Application for Online Learning at Madrasah Ibtidaiyah Negeri (Islamic State Elementray School) 1 Ketapang Academic Year 2020/2021.The Implementation of Practical Assistance as an Effort to Enhance Teacher Competence in Optimizing Goole Form Application for Online Learning at Madrasah Ibtidaiyah Negeri (Islamic State Elementray School) 1 Ketapang Academic Year 2020/2021. The purpose of this study is to to develop teacher's competence in bulding Google Form to improve the quality of learning and assessment. This research is a School Action Research which consists of 2 cycles, with the participatory observation from 15 teachers. Each cycle entails of planning, implementing, observing and reflecting. Based on the results of predetermined steps related to the research, there is an improvement in teacher ability compares before practical assessment is implemented and after it is implemented. The competence of teachers in making Goggle Form applications before practical assessment activities is in the range of values of $28 \%$ with the criterion for the score is Less. 2) Teacher's competence in optimizing the Google Form application after the first stage reached values of $68 \%$ of satisfactory criteria. As in advance, after the second stage is practically completed, the score reached $86 \%$, determined as more satisfactory criteria compared from the previous stage.
\end{abstract}

\section{Keyterm: Google Form, Teacher Competence, Practical Assistance}

\begin{abstract}
Abstrak
Pelaksanaan Kegiatan Bimbingan Teknis Sebagai Upaya Meningkatkan Kompetensi Guru Dalam Pembuatan Aplikasi Goole Form Pada Madrasah Ibtidaiyah Negeri 1 Ketapang Tahun Pelajaran 2020/2021" Adapun tujuan penelitian ini adalah untuk mengetahui kompetensi guru Madrasah Ibtidaiyah Negeri 1 Ketapang dalam membuat aplikasi Google Form sebagai alat dalam mendukung proses pembelajaran dan penilaian pembelajaran sehingga dapat meningkatkan kualitas pembelajaran dan penilaian. Penelitian ini adalah Penelitian Tindakan Sekolah yang terdiri dari 2 siklus, dengan bantuan lembar observasi partisipasi dari 15 orang guru. Setiap siklus terdiri dari perencanaan, pelaksanaan, pengamatan dan refleksi. Berdasarkan hasil penelitian terkait dengan kompetensi guru dalam membuat aplikasi google form berdasarkan langkah-langkah yang sudah ditetapkan terdapat peningkatan kemampuan guru dari sebelum dilaksanakan bimbingan teknis dan sesudah dilaksanakan bimbingan teknis. Kompetensi guru Madrasah Ibtidaiyah Negeri 1 Ketapang dalam membuat aplikasi Goggle Form sebelum kegiatan bimbingan teknis berada pada rentang nilai $28 \%$ dengan kriteria nilai Kurang. 2) Kompetensi guru Madrasah Ibtidaiyah Negeri 1 Ketapang dalam membuat aplikasi Goggle Form setelah dilakukan kegiatan bimbingan teknis tahap I kemudian dilakukan penelitian pada siklus I, berada pada rentang nilai 68\% dengan kriteria Cukup. Selanjutnya, setelah dilakukan bimbingan teknis tahap II kemudian dilakukan penelitian pada siklus II diperoleh nilai pada rentang $86 \%$ dengan kriteria Baik.
\end{abstract}

Kata Kunci : Google form, Kompetensi Guru, Bimbingan Teknis

\section{PENDAHULUAN}

Undang-Undang RI No. 20 Tahun 2003 pasal

3 menyebutkan bahwa Pendidikan Nasional berfungsi mengembangkan kemampuan dan membentuk watak serta peradaban bangsa yang 
bermartabat dalam rangka mencerdaskan kehidupan bangsa, bertujuan untuk berkembangnya potensi peserta didik agar menjadi manusia yang beriman dan bertaqwa kepada Tuhan Yang Maha Esa berakhlak mulia, berilmu cakap kreatif, mandiri dan menjadi warga negara yang demokratis dan bertanggung jawab.

Dengan demikian, pendidikan adalah proses merubah manusia menjadi lebih baik, lebih mahir dan lebih terampil sehingga akan terwujud manusia Indonesia yang kecerdasan baik kecerdasan spritual maupun kecerdasan emosional. Kecerdasan spiritual yang dimiliki oleh anak bangsa yang terampil akan berkonsekwensi kepada kepiawaian dalam mengelola kecerdasan emosional. Bagi seorang tenaga pendidik, kecerdasan dalam proses pelaksanaan tugas keguruan sangatlah penting, hal ini dilakukan agar dapat senantiasa ekses dalam perkembangan ilmu pengetahuan dan teknologi.

Terjadinya musibah pendemi Covid-19 yang melanda seluruh belahan dunia, masyarakat Indonesia terutama dunia pendidikan mengalami hambatan dalam proses pembelajaran yaitu pembelajaran tatap muka, sehingga menuntut pemerintah membuat berbagai kebijakan agar proses pembelajaran tetap berjalan. "Prinsip kebijakan pendidikan di masa pandemi Covid-19 adalah mengutamakan kesehatan dan keselamatan peserta didik, pendidik, tenaga kependidikan, keluarga, dan masyarakat secara umum, serta mempertimbangkan tumbuh kembang peserta didik dan kondisi psikososial dalam upaya pemenuhan layanan pendidikan selama pandemi Covid-19. Hal ini tertuang dalam Surat Edaran Menteri Pendidikan dan Kebudayaan Nomor 4 Tahun 2020 tentang Pelaksanaan Pendidikan Dalam Masa Darurat Coronavirus Disease (Covid19).

Berdasarkan kebijakan yang dikeluarkan oleh pemerintah tersebut, maka satuan pendidikan mempunyai tugas dan tanggung jawab dalam melaksanakan proses pembelajaran yang telah ditentukan yaitu pembelajaran jarak jauh/daring. Proses pembelajaran daring yang dilakukan oleh guru pada satuan pendidikan menuntut kemampuan guru dalam menggunakan beberapa aplikasi yang terdapat dalam peralatan IT dalam hal ini laptop atau HP.

Guru memiliki peranan yang sangat penting dalam hal menyukseskan program pemerintah terkait dengan pembelajaran daring ini, sehingga guru dituntut untuk lebih banyak belajar terkait dengan pemanfaatan teknologi dalam rangka mendukung proses pembelajaran daring tersebut. Selain itu, pengetahuan yang diperoleh oleh guru pada masa pandemic covid-19 ini berimplikasi terhadap kompetensi keguruan itu sendiri yaitu kompetensi profesionalnya. Kondisi nyata dilapangan, bahwasanya tidak semua guru mampu untuk menggunakan IT dengan baik sebagai media yang mendukung pembelajaran daring, sehingga diperlukan pelatihan yang dapat membantu mereka dalam proses pembelajaran.

Berdasarkan pengamatan terhadap guru Madrasah Ibtidaiyah Negeri 1 Ketapang terkait dengan kemampuan dalam pemanfaatan aplikasi yang mendukung kegiatan pembelajaran dan penilaian dalam hal ini aplikasi google form, masih rendah. Pada hal di masa pendemi covid-19 ini guru dituntut untuk dapat menggunakan media atau alat yang dapat membantu pada proses kegiatan pembelajaran. Dari 35 orang guru di Madrasah Ibtidaiyah Negeri 1 Ketapang, berdasarkan pengamatan kepala madrasah, hanya 3 orang atau $8,57 \%$ yang menggunakan aplikasi google form dalam pembelajaran dan pelaksanaan penilaian. Padahal aplikasi ini sangat membantu dalam kinerja guru. Oleh karena itu, ada kemungkinan guru-guru belum bisa untuk membuat akun aplikasi sehingga mereka terkesan begitu asing dengan aplikasi ini.

Jejen Musfah (2012: 27) Kompetensi adalah kumpulan pengetahuan, perilaku, dan keterampilan yang harus dimiliki guru untuk mencapai tujuan pembelajaran dan pendidikan. Kompetensi diperoleh melalui pendidikan, pelatihan, dan belajar mandiri dengan memanfaatkan sumber belajar. Sementara itu, Muhibbin Syah (2000) menyebutkan bahwa "kompetensi" adalah kemampuan, kecakapan, keadaan berwenang, atau memenuhi syarat menurut ketentuan hukum. Selanjutnya masih menurut Syah, dikemukakan bahwa kompetensi guru adalah kemampuan seorang guru dalam melaksanakan kewajibankewajibannya secara bertanggung jawab dan layak.

McAhsan (1981), sebagaimana dikutip oleh Mulyasa (2003) mengemukakan bahwa kompetensi: “...is a knowledge, skills, and abilities or capabilities that a person achieves, which become part of his or her being to the extent he or she can satisfactorily perform particular cognitive, affective, and psychomotor behaviors". Dalam hal ini, kompetensi diartikan sebagai pengetahuan, keterampilan, dan kemampuan yang dikuasai oleh seseorang yang telah menjadi bagian dari dirinya, sehingga ia dapat melakukan perilaku-perilaku kognitif, afektif, dan psikomotorik dengan sebaikbaiknya.

Suyanto dan Asep Jihad (2013:39) Kompetensi pada dasarnya merupakan deskripsi tentang apa yang dapat dilakukan seseorang dalam bekerja, serta apa wujud dari pekerjaan tersebut yang dapat terlihat. Untuk dapat melakukan suatu pekerjaan, seseorang harus memiliki kemampuan dalam bentuk pengetahuan, sikap dan ketrampilan yang relevan dengan bidang pekerjaannya. Berdasarkan pendapat di atas, kompetensi adalah 
kemampuan seseorang yang berkaitan dengan keterampilan mengelola kinerja dengan efektif dan atau unggul dalam suatu pekerjaan sebagai perwujudan dari kewajiban dan tanggung jawab.

Kompetensi Guru. Menurut Undang-undang No.14 tahun 2005 tentang Guru Dan Dosen pasal 10 ayat (1) kompetensi guru meliputi kompetensi pedagogik, kompetensi kepribadian, kompetensi sosial, dan kompetensi profesional yang diperoleh melalui pendidikan profesi. Salah satu kompetensi yang wajib dimiliki oleh seorang guru seperti diamanatkan dalam Peraturan pemerintah di atas sekaligus terkait dengan proses pembelajaran dan penilaian adalah kompetensi pedagogik. Dalam Undang-undang No. 14 Tahun 2005 tentang Guru dan Dosen dikemukakan kompetensi pedagogik adalah "kemampuan mengelola pembelajaran peserta didik".

Peningkatkan kemampuan dan kompetensi guru dalam melaksanakan tugas profesinya, dapat dilakukan dengan mencakup kegiatan-kegiatan yang bertujuan untuk perbaikan dan pertumbuhan kemampuan (abilities), sikap (attitude), dan keterampilan (skill). Kegiatan ini diharapkan akan menghasilkan suatu perubahan perilaku guru yang secara nyata perubahan perilaku tersebut berdampak pada peningkatan kinerja guru dalam proses belajar mengajar di kelas. Meningkatkan Kompetensi Guru merupakan sebagai salah satu cara untuk memenuhi standar kompetensi guru sesuai dengan tuntutan profesi dan perkembangan ilmu pengetahuan, teknologi, dan seni. Meningkatkan Kompetensi Guru menjadi bagian penting yang harus selalu dilakukan secara terus menerus atau berkelanjutan untuk menjaga profesionalitas guru. (Lalu Sahdan; 2020).

Meningkatkan kompetensi guru merupakan sebagai salah satu cara untuk memenuhi standar kompetensi guru sesuai dengan tuntutan profesi dan perkembangan ilmu pengetahuan, teknologi, dan seni. Meningkatkan kompetensi Guru menjadi bagian penting yang harus selalu dilakukan secara terus menerus atau berkelanjutan untuk menjaga profesionalitas guru. (Lalu Sahdan; 2020).

Kompetensi guru mengandung arti kemampuan seorang guru dalam melaksanakan kewajiban, tugas, tanggung jawab serta peranannya secara layak dan profesional sesuai standar yang ditetapkan dalam profesi guru (Usman, 2005). Sementara itu menurut Hamatih (2006), kompetensi guru terdiri dari empat kompetensi utama yaitu kompetensi pedagogik, kompetensi sosial, kompetensi akademik, dan kompetnsi kepribadian. Guru yang memiliki keempat kompetensi itu secara maksimal akan lebih mampu mengelola kelasnya sehingga belajar para siswa berada pada tingkat optimal

Adapun yang dimaksud kompetensi guru dalam penelitian ini adalah kemampuan dan ketrampilan guru di Madrasah Ibtidaiyah Negeri 1 Ketapang dalam membuat aplikasi google form sebagai alat untuk proses penilaian pembelajaran (penilaian harian dan penilaian semester).

Pengertian Aplikasi Google Form. Google form adalah layanan dari Google yang memungkinkan anda untuk membuat survey, tanya jawab dengan fitur formulir online yang bisa dicustomisasi sesuai dengan kebutuhan. Jadi anda bisa mendapatkan jawaban secara langsung dari audiens yang mengikuti survey.

Google saat ini terus melakkan inovasi dari berbagai platform yang dimilikinya, di antaranya google docs, yang salah satu fiturnya turut menghadirkan Google form. Biasanya digunakan untuk beberapa hal seperti memebuat kuisioner, membuat quick count pendapat, membuat fomulir pendaftaan online, kemudian mengelolanya dan masih banyak lagi. (https://qwords.com/blog/mengenal-google-form/ diakses pada tangga 30 Desember 2020)

Google Forms adalah alat yang memungkinkan mengumpulkan informasi dari pengguna melalui survei ataupun kuis yang dipersonalisasi. Informasi tersebut kemudian dikumpulkan dan secara otomatis terhubung ke spreadsheet. Spreadsheet diisi dengan survei dan respons kuis.

(https://id.wikipedia.org/wiki/Google_Formu lir, diakses pada tanggal 18 Desember 2020).

Pada Juli 2017, Google memperbarui Formulir untuk menambahkan beberapa fitur baru. "Validasi respons cerdas" mampu mendeteksi input teks dalam bidang formulir untuk mengidentifikasi apa yang tertulis dan meminta pengguna untuk mengoreksi informasi jika salah memasukkan. Bergantung pada pengaturan berbagi file di Google Drive, pengguna dapat meminta unggahan file dari individu di luar perusahaannya masing-masing, dengan batas penyimpanan awalnya ditetapkan pada $1 \mathrm{~GB}$, yang dapat diubah menjadi 1 TB. Kotak centang baru memungkinkan jawaban multi-opsi dalam tabel. Di Pengaturan, pengguna dapat membuat perubahan yang memengaruhi semua formulir baru, seperti selalu mengumpulkan alamat email. (https://id.wikipedia.org/wiki/Google_Formulir, diakses pada tanggal 18 Desember 2020).

Kegunaan Aplikasi Google Form. Seperti halnya Google Docs dan Google Sheets, Google Form adalah salah satu bagian dari fitur-fitur Google yang dapat diakses melalui browser secara gratis. Fitur ini dapat mengumpulkan informasi dari banyak responden untuk berbagai kebutuhan.

Informasi yang masuk melalui Google Form kemudian akan disimpan di spreadsheet secara otomatis. Selain menyimpan, data pada spreadsheet juga dapat diedit sebelum diolah lebih lanjut atau dikirimkan kepada penerima. Karena 
kelebihannya inilah kamu dapat menggunakan google formulir dalam berbagai hal. Beberapa fungsi Google Form misalnya, untuk membuat formulir survei pelanggan, formulir registrasi online, kuis, hingga formulir lamaran kerja. (https://www.ekrut.com/media/cara-membuatgoogle-form) diakses pada tanggal 30 Desember 2020).

\section{Langkah Pembuatan Akun Aplikasi} Google Form. Beberapa orang masih ada yang belum mengerti cara membuat google form, padahal google form akan sangat berguna bagi banyak orang sebab interaksi virtual formal bisa dilakukan di media sosial. Salah satu cara yang bisa dilakukan yakni dengan membuat google form. Cara membuat google form juga tak begitu sulit. Formulir virtual ini juga bersifat gratis sehingga begitu banyak orang menggunakan. Kalian juga tentu bisa memanfaatkan salah satu layanan dari Google ini.

Adapun langkah-langkah dalam pembuatan akun aplikasi google form adalah sebagai berikut: (1) Buat akun Google. Untuk menggunakan Google Form kita harus memiliki akun Google terlebih dahulu. Bila belum memiliki akun Google, buatlah dengan cara seperti biasa. (2) Buka situs google form. Buka https://docs.google.com/forms. Kita bisa memilih berbagai template contoh Google Form dan contoh kuesioner Google Form yang sudah tersedia di sini, mulai dari template informasi kontak, konfirmasi kehadiran acara, undangan pesta, dan sebagainya. (3) Buat form. Untuk mulai membuat form kamu bisa klik langsung di template yang ada. Jika ingin membuat form sndiri, mulailah dengan klik pada bagian form Blank. Buat nama untuk survei yang kamu buat pada kolom Untiteld form, lalu tuliskan deskripsi survei pada kolom Form description. Ketik pertanyaan yang kamu inginkan dalam kolom Untitled Question sesuai data apa yang ingin kamu dapatkan melalui survei tersebut. Kita dapat memilih tipe jawaban yang kamu inginkan. Mulai dari jawaban singkat, paragraf, pilihan ganda, atau kotak centang. Untuk memilih tipe jawaban klik opsi Multiple choice dan kamu akan melihat semua tipe pertanyaan yang tersedia. Tipe pertanyaan terdiri dari Multiple choice, Checkboxes, Short answer and Paragraph, Dropdown, Linear scale, dan Date and Time. Selain itu ada pula pilihan file upload bila kamu membutuhkan tambahan data berupa dokumen atau foto tertentu dari responden.

Untuk mempercantik tampilan form kita dapat menggunakan ikon Palette untuk mengubah warna dan menambahkan foto ke header. Selain itu untuk dapat melihat keseluruhan tampilan dengan klik ikon Eye untuk pratinjau survei. Sementara untuk mengelola peraturan survei, cukup klik ikon Gear. Setelah survei selesai dibuat, klik tombol Send yang ada di pojok kanan atas. Kamu dapat langsung membagikan lik google form tersebut kepada responden. Bisa dengan menyalin link atau membagikannya langsung dengan memasukkan email responden.

Cara Membagikan Google Form. Setelah selesai membuat Google Form, ada beberapa cara yang bisa di lakukan untuk membagikan atau mengirimkannya kepada responden. Google Form dikirim langsung ke email responden, mengirim link Google form ke penerima atau menanamkan HTML Google Form ke postingan blog dan landing page dengan mengikuti langkah-langkah berikut: (1) Klik tombol "kirim" di bagian kanan atas formulir kamu. Pilih salah satu dari tiga opsi yang tercantum di sebelah "Send melalui aplikasi WA atau yang lainnya"; (2) Untuk email bisa langsung memasukkan email penerima, subyek dan isi email lalu, lalu klik send; (3) Bisa memilih opsi menyalin link formulir untuk kemudian disebarkan misalnya lewat pesan chat; (4) Klik logo $<$ embed HTML bila kamu ingin menanamkan Google form ke dalam postingan blog atau landing page; (5) elain beberapa opsi di atas, juga dapat membagikan Google Form ke media sosial dengan memilih ikon Facebook atau Twitter yang ada di samping pilihan opsi sebelumnya. (https://www.ekrut.com/media/caramembuat-google-form) diakses pada tanggal 30 Desember 2020.

Cara Melihat Respon Survey di Google Form. Langkah selanjutnya adalah menunggu respons pada survei yang kamu buat. Begitu respons masuk, kamu tidak perlu melakukan langkah ekstra untuk menyimpannya. Cukup klik tab bertuliskan Response, lalu kamu akan mendapatkan grafik kesimpulan dan daftar jawaban. Guna menganalisis jawaban yang masuk, kamu dapat menghubungkan form tersebut pada spreadsheet Google Sheets. Caranya, klik ikon Sheets berwarna hijau pada tab Response, atau klik Select Response Destination pada menu. Setelah itu, bisa membuat spreadsheet baru maupun memasukkan data-data tersebut ke dalam spreadsheet yang telah dibuat sebelumnya. Ketika surveimu mendapatkan respons baru, respons akan masuk secara otomatis ke dalam spreadsheet tersebut. Dari sini, kita dapat mengolah seluruh data yang masuk sesuai kebutuhan, juga bisa membagikan dan mengedit formulir, respons, serta hasil survei kepada semua orang yang memerlukannya.

Bimbingan Teknis. Bimtek adalah akronim dari Bimbingan Teknis. Bimbingan Teknis memiliki pengertian sebagai sebuah layanan bimbingan dan penyuluhan yang diberikan oleh tenaga ahli atau profesional dibidangnya dengan tujuan meningkatkan kualitas Sumber Daya Manusia. Seiring dengan jaman yang terus berkembang, Bimbingan Teknis atau Bimtek 
memiliki peran yang sangat penting dalam meningkatkan kualitas sumber daya manusia.

Bimbingan teknis adalah suatu kegiatan yang dimaksukan untuk memberikan bantuan yang biasanya berupa tuntunan dan nasehat untuk menyelesaikan persoalan/masalah yang bersifat teknis. Bimbingan teknis merupakan kegiatan pelatihan dan pengembangan pengetahuan serta kemampuan yang dapat digunakan untuk memecahkan masalah yang dihadapi oleh individu maupun institusi tertentu, sehingga dengan mengikuti bimbingan teknis dapat mengambil sebuah manfaat dengan berorientasi pada kinerja.

Bimbingan Teknis (BIMTEK) adalah pelatihan yang biasanya dilaksana oleh lembaga resmi dengan tujuan untuk meningkatkan kompetensi peserta yang dimana materi yang diberikan meliputi Membangun Tim Kerja Efektif, Teknik Komunikasi dalam Konteks Pelayanan Prima, Survey Indeks Kepuasan Masyarakat dan Penanganan Keluhan Pelanggan, Tata Pemerintahan yang Baik dan Profesionalisme Aparatur, Kepemimpinan, dll (Ditjen POLPUN Kementerian Dalam Negeri Republik Indonesia).

Bimtek ini dimaksudkan untuk turut serta membantu pemerintah Republik Indonesia dalam memajukan pendidikan umum, kesejahteraan dan keamanan demi kepentingan bangsa dan negara, dalam mewujudkan masyarakat adil dan makmur. Membantu program pemerintah dalam meningkatkan kinerja Aparatur dalam menjalankan tugas pemerintahan dan mengsosialisasikan serta mensikronisasikan antara kebijakan pemerintah pusat dengan pemerintah daerah agar kebijakan pemerintah pusat dapat di pahami dan di jalankan dengan baik oleh pemerintah daerah agar target pembangunan dapat tercapai dan kesejahteraan bangsa Indonesia dapat terwujudkan serta terciptanya pemerintahan yang baik di seluruh Indonesia. (Ditjen POLPUN Kementerian Dalam Negeri Republik Indonesia).

Secara umum tujuan dari Bimbingan Teknis meliputi: (1) Peningkatan kualitas Sumber Daya manusia; (2) Koordinasi yang lebih baik; (3) Peningkatan kinerja institusi dan organisasi untuk menunjang keberhasilan suatu institusi; (4) Memiliki kompetensi untuk secara optimal melaksanakan tugas jabatan yang diduduki; (5) Memiliki kompetensi untuk menduduki jabatan yang lebih tinggi

Berdasarkan pengertian dan maksud dari bimtek di atas, maka kegiatan bimbingan teknis yang dilakukan dalam rangka memperoleh kemajuan dalam berbagai bidang. Jika bimtek tersebut terkait dengan kompetensi guru maka tujuan yang diharapkan adanya peningkatan dan kemajuan dalam bidang kompetensi guru.

Bimtek umumnya diadakan selama 2 hingga 3 hari tergantung pada materi yang dipilih. Hal ini bertujuan untuk memudahkan peserta didik dalam mendalami materi yang diajarkan atau diberikan oleh tenaga ahli. Selain itu adapun tujuan lainnya yaitu sebagai sarana penyegaran diri (refreshing) sehingga ketika peserta didik kembali ke pekerjaannya, diharapkan dapat lebih fokus dengan pekerjaanya.

Kerangka Pikir. Dalam pelaksanaan penelitian tindakan sekolah ini dilakukan secara tersetruktur artinya seluruh kegiatan direncanakan sesuai dengan kesepakatan dengan guru-guru yang menjadi obyek penelitian. Terkait dengan proses pengumpulan data melalui teknik yang sudah ditentukan oleh peneliti, disepakati waktu yang tepat untuk proses tersebut sehingga guru-guru merasa fres dan tidak tertekan. Adapun alur kerangka berfikir pelaksanaan penelitian tindakan sekolah ini adalah sebagai berikut:

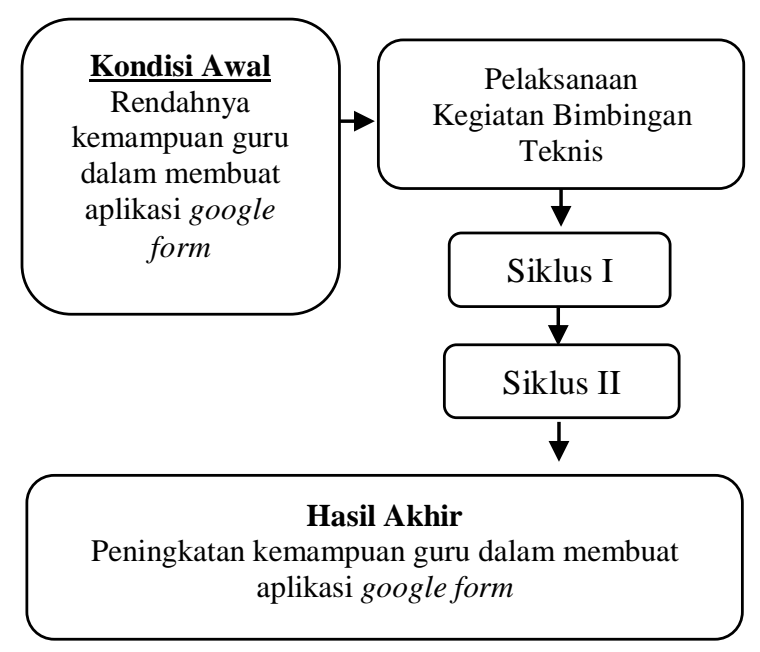

\section{Gambar 1. Bagian Alur Kerangka Berfikir Pelaksanaan PTS}

\section{METODE PENELITIAN}

Jenis dan Pendekatan Penelitian. Jenis penelitian ini adalah penelitian tindakan yaitu menerapkan suatu tindakan yang tujuannya adalah meningkatkan mutu serta terselesaikannya masalah yang dihadapi oleh suatu kelompok subyek yang diteliti. Penelitian tindakan merupakan suatu proses sistematik yang dilaksanakan oleh para pelaksana program dalam kegiatannya sendiri (dalam pendidikan dilakukan oleh guru, dosen, dll), dalam mengumpulkan data tentang pelaksanaan kegiatan, keberhasilan dan hambatan yang dihadapi, untuk kemudian menyusun rencana dan melakukan kegiatan-kegiatan lain untuk penyempurnaan.

Penelitian ini adalah Penelitian Tindakan Sekolah. Penelitian Tindakan Sekolah merupakan "(1) penelitian partisipatoris yang menekankan pada tindakan dan refleksi berdasarkan pertimbangan rasional dan logis untuk melakukan perbaikan terhadap suatu kondisi nyata; (2) 
memperdalam pemahaman terhadap tindakan yang dilakukan; dan (3) memperbaiki situasi dan kondisi sekolah / pembelajaran secara praktis" (Depdiknas, $2008: 11-12$ ).

Suharsimi Arikunto (2010: 135), mengemukakan bahwa penelitian tindakan sekolah (school action research) adalah penelitian yang dilakukan oleh pihak pengelola sekolah sebagai sebuah organisasi pendidikan untuk meningkatkan kinerja, proses, dan produktivitas lembaga.

Metode yang digunakan dalam penelitian ini adalah metode deskriptif, dengan menggunakan teknik persentase untuk melihat peningkatan yang terjadi dari siklus ke siklus. Metode deskriptif dapat diartikan sebagai prosedur pemecahan masalah yang diselidiki dengan menggambarkan/melukiskan keadaan subjek penelitian seseorang, lembaga, masyarakat, dan lainlain pada saat sekarang berdasarkan fakta-fakta yang tampak atau sebagaimana adanya (Nawawi, 1985:63). Dengan metode ini peneliti berupaya menjelaskan data yang dikumpulkan melalui observasi/pengamatan dan diskusi yang dijabarkan dalam bentuk persentase atau angka-angka.

Moleong (2001:6) mengatakan bahwa "Penelitian kualitatif deskriptif adalah penelitian yang bermaksud untuk memahami fenomena tentang apa yang dialami oleh subjek penelitian misalnya perilaku, persepsi, motivasi, tidakan".

Tempat dan Waktu Penelitian. Penelitian Tindakan Sekolah ini dilaksanakan di Madrasah Ibtidaiyah Negeri 1 Ketapang, jalan S. Parman Sukaharja Kecamatan Delta Pawan Kabupaten Ketapang Provinsi Kalimantan Barat, dengan lama waktu penelitian selama 3 bulan, dimulai dari bulan Juli 2020 sampai dengan bulan September 2020.

Subjek Penelitian. Adapun yang menjadi subjek dalam penelitian ini adalah guru Madrasah Ibtidaiyah Negeri 1 Ketapang yang mengajar di kelas 4 s.d kelas 6 berjumlah 15 orang, terdiri dari guru kelas dan guru mata pelajaran.

Rancangan Penelitian. Rancangan penelitian adalah semua rencana yang akan dilaksanakan oleh seorang peneliti dalam penelitian untuk menyelesaikan suatu masalah yang sedang diteliti. Penelitian Tindakan Sekolah (PTS) ini dirancang dengan 2 siklus penelitian dengan langkah-langkah sebagai berikut:

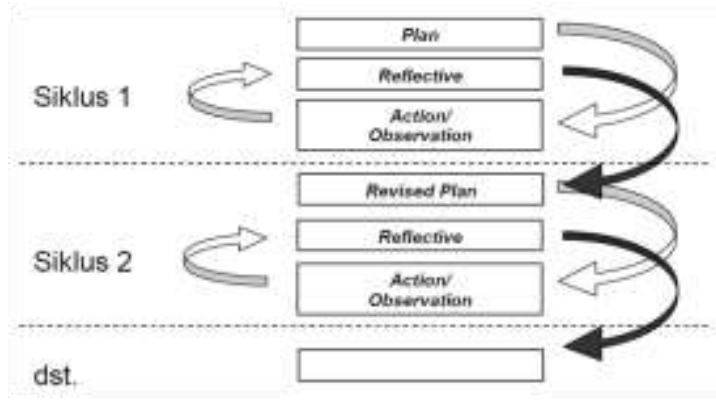

Indikator Kinerja. Indikator kinerja yang ditetapkan adalah meningkatkan kemampuan guru dalam membuat aplikasi google form bagi guru Madrasah Ibtidaiyah Negeri 1 Ketapang. Guru dinyatakan meningkat kemampuannya dalam membuat aplikasi google form apabila secara individual memenuhi rentang 76-100 atau masuk kategori BAIK, dan secara klasikal apabila minimal $76 \%$ termasuk dalam kategori BAIK.

\section{HASIL PENELITIAN DAN PEMBAHASAN Paparan Data Hasil Penelitian}

Kondisi Awal. Berdasarkan hasil observasi yang peneliti lakukan terhadap responden 15 orang guru yang mengajar di kelas 4 s.d 6 tanggal 20 s.d 21 Juli 2020 terkait dengan kompetensi dalam membuat aplikasi google form sebagai alat untuk mendukung proses pembelajaran dan penilaian pembelajaran, diperoleh informasi sebagaimana terdapat dalam tabel berikut:

Tabel 1. Kompetensi Guru Menggunakan Aplikasi Google Form (Awal)

\begin{tabular}{|c|c|c|c|}
\hline No. & $\begin{array}{l}\text { Kode } \\
\text { Guru } \\
\end{array}$ & $\begin{array}{c}\text { Persentase } \\
\text { Capaian }\end{array}$ & $\begin{array}{c}\text { Kriteria } \\
\text { Nilai }\end{array}$ \\
\hline 1. & 001 & $0 \%$ & $\begin{array}{c}\text { Sangat } \\
\text { Kurang }\end{array}$ \\
\hline 2. & 002 & $100 \%$ & Baik \\
\hline 3. & 003 & $46 \%$ & Kurang \\
\hline 4. & 004 & $15 \%$ & $\begin{array}{l}\text { Sangat } \\
\text { Kurang }\end{array}$ \\
\hline 5. & 005 & $0 \%$ & $\begin{array}{l}\text { Sangat } \\
\text { Kurang }\end{array}$ \\
\hline 6. & 006 & $100 \%$ & Baik \\
\hline 7. & 007 & $0 \%$ & $\begin{array}{l}\text { Sangat } \\
\text { Kurang }\end{array}$ \\
\hline 8. & 008 & $0 \%$ & $\begin{array}{l}\text { Sangat } \\
\text { Kurang }\end{array}$ \\
\hline 9. & 009 & $38 \%$ & Kurang \\
\hline 10. & 010 & $8 \%$ & $\begin{array}{l}\text { Sangat } \\
\text { Kurang }\end{array}$ \\
\hline 11. & 011 & $0 \%$ & $\begin{array}{l}\text { Sangat } \\
\text { Kurang }\end{array}$ \\
\hline 12. & 012 & $0 \%$ & $\begin{array}{l}\text { Sangat } \\
\text { Kurang }\end{array}$ \\
\hline 13. & 013 & $23 \%$ & $\begin{array}{l}\text { Sangat } \\
\text { Kurang }\end{array}$ \\
\hline 14. & 014 & $10 \%$ & $\begin{array}{l}\text { Sangat } \\
\text { Kurang }\end{array}$ \\
\hline \multirow[t]{2}{*}{15.} & 015 & $8 \%$ & $\begin{array}{l}\text { Sangat } \\
\text { Kurang }\end{array}$ \\
\hline & $\begin{array}{c}\text { Rata- } \\
\text { rata }\end{array}$ & $28 \%$ & Kurang \\
\hline
\end{tabular}

Dari penjelasan tabel di atas dapat dijabarkan bahwa pada kondisi awal sebelum pelaksanaan kegiatan bimbingan teknis pembuatan aplikasi google form, dari 15 orang guru terdapat 2 (dua) 
orang yang sudah memiliki kompetensi Baik, 2 (dua) orang memiliki kompetensi Kurang, dan 11 (sebelas) orang memiliki kompetensi Sangat Kurang, dengan rata-rata kemampuan berada pada angka 28\% masih dalam kategori Kurang. (Penilaian per individu masing-masing guru dapat dilihat pada lampiran-lampiran)

\section{Siklus I}

Proses pelaksanaan siklus I menempuh empat tahapan, yakni: (1) perencanaan, (2) pelaksanaan, (3) observasi, dan (4) refleksi. Adapun deskripsi masing-masing tahapan tersebut, sebagai berikut:

Perencanaan. Perencanaan tindakan siklus I dilakukan secara kolaborasi antara peneliti dan guru yang memiliki kategori nilai secara individu baik pada data awal, dengan melaksanakan kegiatan antara lain: (1) Mengidentifikasi masalah terkait dengan kemampuan guru membuat aplikasi google form, antara lain terkait dengan kategori nilai kurang dan sangat kurang pada aspek langkah-langkah pembuatan aplikasi; (2) Menetapkan waktu untuk pelaksanaan bimbingan teknis; (3) Menetapkan kriteria keberhasilan bimbingan teknis pada siklus I sehingga dapat meningkatkan kemampuan dalam membuat aplikasi google form; (4) Menyusun instrumen yang diperlukan, yaitu lembar observasi sebagai alat untuk mengamati guru dalam proses pembuatan aplikasi google form.

Pelaksanaan. Pelaksanaan kegiatan bimbingan teknis penggunaan aplikasi google form bagi guru Madrasah Ibtidaiyah Negeri 1 Ketapang pada bulan Agustus 2020.

Observasi. Observasi peneliti lakukan mulai awal bulan September 2020 setelah kegiatan bimbingan teknis terhadap 15 orang guru yang mengajar di kelas 4 s.d 6 . Berdasarkan hasil observasi diperoleh beberapa catatan serta hasil penilaian terhadap kemampuan masing-masing guru. Berikut ini ringkasnya hasil catatan dan penilaian tersebut.

Tabel 2. Kompetensi Guru Menggunakan Aplikasi Google Form pada Siklus 1

\begin{tabular}{cccc}
\hline No. & $\begin{array}{c}\text { Kode } \\
\text { Guru }\end{array}$ & $\begin{array}{c}\text { Persentase } \\
\text { Capaian }\end{array}$ & $\begin{array}{c}\text { Kriteria } \\
\text { Nilai }\end{array}$ \\
\hline 1. & 001 & $62 \%$ & Cukup \\
\hline 2. & 002 & $100 \%$ & Baik \\
\hline 3. & 003 & $77 \%$ & Baik \\
\hline 4. & 004 & $46 \%$ & Kurang \\
\hline 5. & 005 & $62 \%$ & Cukup \\
\hline 6. & 006 & $100 \%$ & Baik \\
\hline 7. & 007 & $54 \%$ & Cukup \\
\hline 8. & 008 & $54 \%$ & Cukup \\
\hline 9. & 009 & $62 \%$ & Cukup \\
\hline 10. & 010 & $62 \%$ & Cukup \\
\hline
\end{tabular}

\begin{tabular}{cccc}
\hline 11. & 011 & $54 \%$ & Cukup \\
\hline 12. & 012 & $62 \%$ & Cukup \\
\hline 13. & 013 & $62 \%$ & Cukup \\
\hline 14. & 014 & $100 \%$ & Baik \\
\hline 15. & 015 & $69 \%$ & Cukup \\
\hline & $\begin{array}{c}\text { Rata- } \\
\text { rata }\end{array}$ & $\mathbf{6 8 \%}$ & Cukup \\
\hline
\end{tabular}

Dari penjelasan tabel di atas dapat dijabarkan bahwa setelah pelaksanaan kegiatan bimbingan teknis pembuatan aplikasi google form, dari 15 orang guru terdapat 4 (empat) orang yang sudah memiliki kompetensi Baik, 10 (sepuluh) orang memiliki kompetensi Cukup, dan (satu) orang memiliki kompetensi Kurang, dengan ratarata kemampuan berada pada angka 68\% masih dalam kategori Cukup.

Refleksi. Setelah melakukan serangkaian kegiatan siklus I, pada akhirnya diperoleh suatu bahan refleksi untuk didiskusikan bersama para guru Madrasah Ibtidaiyah Negeri 1 Ketapang antara lain: (1) Masing-masing guru mengalami peningkatan kemampuan dalam membuat aplikasi google form, hal ini menunjukkan bahwa kegiatan bimbingan teknis yang dilakukan telah memberi dampak yang positif terhadap meningkatnya kemampuan guru; (2) Terkait dengan beberapa aspek yang menjadi langkah-langkah pembuatan aplikasi masih pada kategori nilai cukup dan kurang, menjadi proritas utama pada tahap selanjutnya; (3) Seiring dengan meningkatnya kemampuan masing-masing guru, terkait dengan pembuatan aplikasi google form, sesuai dengan indikator kerja yang ditetapkan, guru dinyatakan meningkat kemampuannya dalam membuat aplikasi google form apabila secara individual memenuhi rentang 76-100 atau masuk kategori BAIK, dan secara klasikal apabila minimal 76\% termasuk dalam kategori BAIK.

\section{Siklus II}

Seperti halnya proses pelaksanaan siklus I, pada siklus II pun menempuh beberapa tahapan berikut: (1) perencanaan, (2) pelaksanaan, observasi, dan (4) refleksi. Untuk menggambarkan aktivitas pelaksana tindakan dan subjek, serta aktivitas pengamat untuk mendapatkan data yang diharapkan. Adapun penjelasan pada siklus kedua adalah sebagai berikut:

Perencanaan. Dalam merencanakan tindakan pada siklus II ini, peneliti beserta guru menyusun perencanaan didasarkan pada hasil refleksi siklus I, yaitu membuat skala prioritas terhadap komponen atau aspek langkah-langkah pembuatan aplikasi yang masih dalam kategori cukup dan kurang.

Pelaksanaan. Pelaksanaan kegiatan bimbingan teknis penggunaan aplikasi google form 
bagi guru Madrasah Ibtidaiyah Negeri 1 Ketapang tahap ke II dilaksanakan September 2020.

Observasi. Observasi siklus II ini peneliti lakukan mulai pada bulan September 2020 setelah kegiatan bimbingan teknis tahap II terhadap 15 orang guru yang mengajar di kelas 4 s.d 6 . Berdasarkan hasil observasi diperoleh beberapa catatan serta hasil penilaian terhadap kemampuan masing-masing guru. Berikut ini ringkasnya hasil catatan dan penilaian tersebut.

Tabel 3. Kompetensi Guru Menggunakan Aplikasi Google Form pada Siklus 2

\begin{tabular}{cccc}
\hline No. & $\begin{array}{c}\text { Kode } \\
\text { Guru }\end{array}$ & $\begin{array}{c}\text { Persentase } \\
\text { Capaian }\end{array}$ & Kriteria Nilai \\
\hline 1. & 001 & $85 \%$ & Baik \\
\hline 2. & 002 & $100 \%$ & Baik \\
\hline 3. & 003 & $85 \%$ & Baik \\
\hline 4. & 004 & $77 \%$ & Baik \\
\hline 5. & 005 & $77 \%$ & Baik \\
\hline 6. & 006 & $100 \%$ & Baik \\
\hline 7. & 007 & $85 \%$ & Baik \\
\hline 8. & 008 & $77 \%$ & Baik \\
\hline 9. & 009 & $77 \%$ & Baik \\
\hline 10. & 010 & $85 \%$ & Baik \\
\hline 11. & 011 & $77 \%$ & Baik \\
\hline 12. & 012 & $85 \%$ & Baik \\
\hline 13. & 013 & $77 \%$ & Baik \\
\hline 14. & 014 & $100 \%$ & Baik \\
\hline 15. & 015 & $100 \%$ & Baik \\
\hline & $\begin{array}{c}\text { Rata- } \\
\text { rata }\end{array}$ & $\mathbf{8 6 \%}$ & Baik \\
\hline
\end{tabular}

Dari penjelasan tabel di atas dapat dijabarkan bahwa setelah pelaksanaan kegiatan bimbingan teknis tahap II terkait dengan pembuatan aplikasi google form, 15 orang guru memiliki kriteria nilai Baik, dengan rata-rata kemampuan secara klasikal berada pada angka $86 \%$ dengan kriteria nilai Baik. (Penilaian per individu masing-masing guru dapat dilihat pada lampiran-lampiran).

Refleksi. Setelah melakukan serangkaian kegiatan siklus II, pada akhirnya diperoleh suatu bahan refleksi untuk didiskusikan bersama peneliti beserta dewan guru Madrasah Ibtidaiyah Negeri 1 Ketapang, antara lain: (1) Masing-masing guru mengalami peningkatan kemampuan dalam membuat aplikasi Google Form. Setelah siklus II ini, tidak lagi ditemukan adanya guru yang mengalami kesulitan dalam membuat aplikasi tersebut; (2) Seiring dengan meningkatnya kemampuan masing-masing guru dalam membuat aplikasi Google Form, maka diharapkan dapat membantu guru dalam proses pembelajaran dan penilaian di masa covid-19 ini; (3) Terbukti bahwasanya kegiatan bimbingan teknis yang dilaksanakan oleh madrasah dapat membantu meningkatkan kompetensi guru.

\section{Pembahasan Hasil Penelitian}

Berdasarkan data yang telah dipaparkan di atas terkiat dengan kemampuan guru dalam membuat aplikasi google form sebagai alat untuk membantu proses pembelajaran dan penilaian, terutama di masa pandemik covid-19 ini, sebelum dilaksanakannya kegiatan bimbingan teknis diperoleh nilai $28 \%$ atau dalam kriteria nilai kurang. Selanjutnya setelah dilaksanakan kegiatan bimbingan teknis membuat akun aplikasi google form terhadap guru-guru, maka pada siklus I diperoleh nilai sebesar $68 \%$ dengan kriteria nilai Cukup.

Berdasarkan Indikator kinerja yang telah ditetapkan, bahwa peningkatan kemampuan guru terkait dengan pembuatan aplikasi google form dinyatakan meningkat kemampuannya apabila secara individual memenuhi rentang 76-100 atau masuk kategori Baik, dan secara klasikal apabila minimal $76 \%$ termasuk dalam kategori Baik, oleh karena itu dilaksanakan bimbingan teknis tahap II. Hasil kemampuan guru pada siklus II terkait dengan pembuatan aplikasi google form diperoleh nilai secara klasikal 86\% dalam kategori Baik.

\begin{tabular}{|c|c|c|c|}
\hline abel & $\begin{array}{r}\text { Reka } \\
\text { MeI } \\
\text { For }\end{array}$ & $\begin{array}{l}\text { ulasi Kom } \\
\text { unakan A } \\
\text { pada Siklus }\end{array}$ & $\begin{array}{ll}\text { ensi } & \text { Guru } \\
\text { asi } & \text { Google } \\
\text { an } 2 & \end{array}$ \\
\hline No & $\begin{array}{c}\text { Uraian } \\
\text { Kegiatan }\end{array}$ & $\begin{array}{c}\text { Rata-Rata } \\
\text { Capaian }\end{array}$ & $\begin{array}{c}\text { Kriteria } \\
\text { Nilai }\end{array}$ \\
\hline 1. & Awal & $28 \%$ & Rendah \\
\hline 2. & Siklus I & $68 \%$ & Cukup \\
\hline 3. & Siklus II & $86 \%$ & Baik \\
\hline
\end{tabular}

Dari paparan data di atas menunjukkan bahwa pelaksanaan kegiatan Bimbingan Teknis sangat membantu dalam rangka meningkatkan kompetensi guru, sehingga diharapkan proses pembelajaran dan penilaian pembelajaran semakin berkualitas. Hal ini sesuai dengan rumusan Ditjen POLPUN Kementerian Dalam Negeri Republik Indonesia tentang tujuan dari Bimbingan Teknis meliputi, 1) peningkatan kualitas Sumber Daya manusia, 2) koordinasi yang lebih baik, 3) peningkatan kinerja institusi dan organisasi untuk menunjang keberhasilan suatu institusi, 4) memiliki kompetensi untuk secara optimal melaksanakan tugas jabatan yang diduduki, 5) memiliki kompetensi untuk menduduki jabatan yang lebih tinggi. Guru memiliki peran yang sangat vital dan fundamental dalam membimbing, mengarahkan, dan mendidik siswa dalam proses pembelajaran (Davies dan Ellison,1992). Peran sebagai agent of change melalui proses pembelajaran, maka guru harus memiliki persyaratan sebagaimana dikemukakan (Hartoyo dan Baedhowi, 2005) antara lain keterampilan 
mengajar (teaching skills), berpengetahuan (knowledgeable), memiliki sikap profesional (good professional attitude), memilih, menciptakan dan menggunakan media (utilizing learning media), memilih strategi dan metode mengajar yang sesuai, memanfaatkan teknologi (utilizing technology), mengembangkan dynamic curriculum, dan bisa memberikan contoh dan teladan yang baik (good practices).

Kemampuan guru dalam pemanfaatan IT diharapkan dapat mendukung secara optimal peningkatan kemampuan profesional guru dalam pembelajaran di sekolah terkait. Kata "profesional" erat kaitannya dengan kata "profesi". Profesi adalah pekerjaan yang untuk melaksanakannya memerlukan sejumlah persyaratan tertentu (Wirawan, 2002: 9). Definisi ini menyatakan bahwa suatu profesi menyajikan jasa yang berdasarkan ilmu pengetahuan yang hanya difahami oleh orang-orang tertentu yang secara sistematik diformulasikan dan diterapkan untuk memenuhi kebutuhan klien, dalam hal ini masyarakat.

\section{SIMPULAN DAN SARAN Simpulan}

Berdasarkan hasil penelitian dan pembahasan yang telah dijabarkan pada bab sebelumnya, Penelitian Tindakan Sekolah (PTS) dapat disimpulkan sebagai berikut: (1) Kompetensi guru Madrasah Ibtidaiyah Negeri 1 Ketapang dalam membuat aplikasi Goggle Form sebelum kegiatan bimbingan teknis berada pada rentang nilai $28 \%$ dengan kriteria nilai Kurang; (2) Kompetensi guru Madrasah Ibtidaiyah Negeri 1 Ketapang dalam membuat aplikasi Goggle Form setelah dilakukan kegiatan bimbingan teknis tahap I kemudian dilakukan penelitian pada siklus I, berada pada rentang nilai $68 \%$ dengan kriteria Cukup. Selanjutnya, setelah dilakukan bimbingan teknis tahap II kemudian dilakukan penelitian pada siklus II diperoleh nilai pada rentang $86 \%$ dengan kriteria Baik.

\section{Saran}

Telah terbukti bahwa dengan dilakukannya kegiatan bimbingan teknis dapat meningkatkan kompetensi guru. Oleh karena itu, peneliti menyampaikan beberapa saran sebagai berikut: (1) Kepada Kantor Kementerian Agama Kabupaten Ketapang untuk dapat memberikan anggaran dalam rangka kegiatan pengembangan kompetensi guru di Madrasah Ibtidaiyah Negeri 1 Ketapang setiap tahunnya; (2) Kepada pihak terkait dalam hal ini Kasi Pendidikan Madrasah Kantor Kementerian Agama Kabupaten Ketapang serta Pengawas Pembina MIN 1 Ketapang untuk lebih kontinyu dalam memberikan pembinaan dan motivasi kepada guru-guru di madrasah dalam meningkatkan kompetensinya; (3) Kepada seluruh guru agar tidak mudah putus asa untuk selalu berkembang dan maju, karena keberhasilan siswa salah satunya ditentukan oleh kompetensi yang dimiliki oleh guru.

\section{DAFTAR PUSTAKA}

Abdul Hadis dan Nurhayati. (2012) Manajemen Mutu Pendidikan, Bandung: Alfabeta.

Davies,B.dan Ellison, L. (1992). School Development Planning. Harlow: Longman Group U.K. Ltd.

Departemen Pendidikan Nasional. Penelitian Tindakan Sekolah. Direktorat Jenderal Peningkatan Mutu Pendidik dan Tenaga Kependidikan. Jakarta.

Departemen Pendidikan Nasional. 2009. Petunjuk Teknis Pembuatan Laporan Penelitian Tindakan Sekolah Sebagai Karya Tulis Ilmiah Dalam Kegiatan Pengembangan Profesi Pengawas Sekolah. Jakarta.

Depdiknas. (2003). UU RI No.20 Tahun 2003 tentang Sistem Pendidikan Nasional. Jakarta: Depdiknas.

Dinamika Jurnal (2020) Praktik Penelitian Tindakan Kelas Pendidikan Dasar \& Menengah Vol. 10

E. Mulyasa. (2003) Kurikulum Berbasis Kompetensi, Konsep, Karakteristik dan Implementasi. Bandung : Remaja Rosda Karya.

(2009). Manajemen Berbasis Sekolah. Bandung: Remaja Rosdakarya.

Hamatih. (2006) Kurikulum Tingkat Satuan Pendidikan, Bandung: Remaja Rosda Karya.

Jejen Musfah. (2012) Peningkatan Kompetensi Guru : Melalaui Pelatihan dan Sumber Belajar Teori dan Praktik. Jakarta: Kencana

Juliansyah Noor. (2011). Metodologi Penelitian (Skripsi, Tesis, Disertasi \& Karya Ilmiah). Jakarta: Kenjana.

Kemendiknas (2010) Penelitian Tindakan Sekolah. Jakarta.

Lalu Sahdan. (2020) Jurnal Suluh Edukasi. E-Issn 2722-063

Majid. (2008) Perencanaan Pembelajaran Mengembangkan Standar Kompetensi Guru. Bandung: PT Rosda Karya.

Muhibbin Syah. (2000) Psikologi Belajar. Jakarta : PT Raja Grafindo Persada.

Meleong. (2007). Metodelogi Penelitian Kualitatif. Bandung: Remaja Rosdakarya.

Sugiyono. (2011) Metode Penelitian Pendidian Pendekatan Kuantitatif, Kualitatif dan $R \& D$. Bandung: Alfabeta.

Suharsimi Arikunto. (2006) Metodologi Penelitian. Penerbit PT. Rineka Cipta. Jakarta. 
(2009) Penelitian tindakan kelas. Jakarta: Bumi Aksara.

(2010) Prosedur Penelitian

Suatu Penelitian Pendekatan Praktek-Cet.14. Jakarta: Rineka Cipta.

Suyanto dan Asep Jihad. (2013) Menjadi Guru Profesional: Strategi MeningkatkanKualifikasi dan Kualitas Guru di Era Globalisasi, Jakarta: Erlangga.
Usman. (2005) Menjadi Guru Profesional, Bandung: Remaja Rosda Karya.

Undang-undang Nomor 20 Tahun 2003 Tentang Sistem Pendidikan Nasional

Undang-Undang No.14 Tahun 2005. Guru dan Dosen. Yogyakarta: Pustaka Pelajar Offset. 